\title{
Front Matter: Volume 7532
}

, "Front Matter: Volume 7532," Proc. SPIE 7532, Image Processing: Algorithms and Systems VIII, 753201 (16 February 2010); doi: $10.1117 / 12.858390$

SPIE Event: IS\&T/SPIE Electronic Imaging, 2010, San Jose, California, United SPIE. States 


\section{PROCEEDINGS \\ IS\&T / SPIE \\ Electronic \\ Imaging \\ SCIENCE AND TECHNOLOGY}

\section{Image Processing: \\ Algorithms and Systems VIII}

Jaakko T. Astola

Karen O. Egiazarian

Editors

19-20 January 2010

San Jose, California, United States

Sponsored and Published by

IS\&T-The Society for Imaging Science and Technology

SPIE 
The papers included in this volume were part of the technical conference cited on the cover and title page. Papers were selected and subject to review by the editors and conference program committee. Some conference presentations may not be available for publication. The papers published in these proceedings reflect the work and thoughts of the authors and are published herein as submitted. The publishers are not responsible for the validity of the information or for any outcomes resulting from reliance thereon.

Please use the following format to cite material from this book:

Author(s), "Title of Paper," in Image Processing: Algorithms and Systems VIII, edited by Jaakko T. Astola, Karen O. Egiazarian, Proceedings of SPIE-IS\&T Electronic Imaging, SPIE Vol. 7532, Article CID Number (2010).

ISSN 0277-786X

ISBN 9780819479259

Copublished by

SPIE

P.O. Box 10, Bellingham, Washington 98227-0010 USA

Telephone +1 3606763290 (Pacific Time) · Fax +1 3606471445

SPIE.org

and

IS\&T-The Society for Imaging Science and Technology

7003 Kilworth Lane, Springfield, Virginia, 22151 USA

Telephone +1 7036429090 (Eastern Time) · Fax +1 7036429094

imaging.org

Copyright (c) 2010, Society of Photo-Optical Instrumentation Engineers and The Society for Imaging Science and Technology.

Copying of material in this book for internal or personal use, or for the internal or personal use of specific clients, beyond the fair use provisions granted by the U.S. Copyright Law is authorized by the publishers subject to payment of copying fees. The Transactional Reporting Service base fee for this volume is $\$ 18.00$ per article (or portion thereof), which should be paid directly to the Copyright Clearance Center (CCC), 222 Rosewood Drive, Danvers, MA 01923. Payment may also be made electronically through CCC Online at copyright.com. Other copying for republication, resale, advertising or promotion, or any form of systematic or multiple reproduction of any material in this book is prohibited except with permission in writing from the publisher. The CCC fee code is $0277-786 \mathrm{X} / 10 / \$ 18.00$.

Printed in the United States of America.

Paper Numbering: Proceedings of SPIE follow an e-First publication model, with papers published first online and then in print and on CD-ROM. Papers are published as they are submitted and meet publication criteria. A unique, consistent, permanent citation identifier (CID) number is assigned to each article at the time of the first publication. Utilization of CIDs allows articles to be fully citable as soon they are published online, and connects the same identifier to all online, print, and electronic versions of the publication. SPIE uses a six-digit CID article numbering system in which:

- The first four digits correspond to the SPIE volume number.

- The last two digits indicate publication order within the volume using a Base 36 numbering system employing both numerals and letters. These two-number sets start with 00, 01, 02, 03, 04, 05 , 06, 07, 08, 09, OA, OB ... 0Z, followed by 10-1Z, 20-2Z, etc.

The CID number appears on each page of the manuscript. The complete citation is used on the first page, and an abbreviated version on subsequent pages. Numbers in the index correspond to the last two digits of the six-digit CID number. 


\section{Contents}

vii Conference Committee

\section{SESSION 1 IMAGING FILTERING}

753202 Latent common origin of bilateral filter and non-local means filter [7532-01]

M. Tanaka, M. Okutomi, Tokyo Institute of Technology (Japan)

\section{SESSION 2 IMAGE PROCESSING ALGORITHMS I}

753204 A new edge detection algorithm in image processing based on LIP-ratio approach [7532-03]

S. Agaian, A. Almuntashri, The Univ. of Texas at San Antonio (United States)

753206 Edge-detected detail enhancement through synthesis of multi-light images [7532-05]

J. Zheng, Z. Li, S. Rahardja, S. Yao, Institute for Infocomm Research, A*STAR (Singapore)

753207 Blurriness estimation in video frames: a study on smooth objects and textures [7532-06]

L. Abate, F. Dardi, G. Ramponi, Univ. di Trieste (Italy)

\section{SESSION 3 IMAGE PROCESSING ALGORITHMS II}

753208 A method for blind estimation of spatially correlated noise characteristics [7532-07]

N. N. Ponomarenko, V. V. Lukin, National Aerospace Univ. (Ukraine); K. O. Egiazarian, J. T. Astola, Tampere Univ. of Technology (Finland)

753209 A robust and fast approach for multiple image components stitching [7532-08] M. Jaber, E. Saber, Rochester Institute of Technology (United States); M. Shaw, J. Hewitt, Hewlett-Packard Corp. (United States)

7532 OA Color-to-grayscale conversion with color clustering and significance criteria [7532-09] P. Majewicz, Hewlett-Packard Corp. (United States)

$7532 \mathrm{OB} \quad$ A voting decision strategy for image registration under affine transformation [7532-11] Y. Almehio, S. Bouchafa, Univ. Paris-Sud XI (France)

7532 OC Key points selection by using Zernike polynomials [7532-12]

L. Costantini, Univ. degli Studi Roma Tre (Italy); F. Mangiatordi, L. Capodiferro, Fondazione Ugo Bordoni (Italy); A. Neri, Univ. degli Studi Roma Tre (Italy)

7532 OD Array set addressing: making the world safe for hexagonal imaging [7532-13] N. I. Rummelt, Air Force Research Lab. (United States); J. N. Wilson, Univ. of Florida (United States) 
7532 OE Efficient implementation of kurtosis based no reference image sharpness metric [7532-14] R. Ferzli, Microsoft Corp. (United States); L. Girija, SirF Technology (United States);

W. S. Ibrahim Ali, Microsoft Corp. (United States)

7532 OF Exploiting DCT masking effect to improve the perceptual quality of data hiding [7532-15] G. Boato, Univ. of Trento (Italy); M. Carli, Univ. degli Studi Roma Tre (Italy); D. Molteni, P. Rota, Univ. of Trento (Italy)

\section{SESSION 4 IMAGE AND VIDEO COMPRESSION}

$7532 \mathrm{OH} \quad$ Multispectral image compression for spectral and color reproduction based on lossy to lossless coding [7532-18]

K. Shinoda, Y. Murakami, M. Yamaguchi, N. Ohyama, Tokyo Institute of Technology (Japan)

7532 Ol Inter-bit prediction based on maximum likelihood estimate for distributed video coding [7532-19]

R. Klepko, D. Wang, G. Huchet, Communications Research Ctr. Canada (Canada)

7532 0J Efficient error frame loss recovery model for scalable video coding (SVC) [7532-44]

W. S. Ibrahim Ali, R. Ferzli, Microsoft Corp. (United States)

\section{SESSION 5 IMAGE RECOGNITION}

7532 OK An unsupervised learning approach for facial expression recognition using semi-definite programming and generalized principal component analysis [7532-20]

B. Gholami, W. M. Haddad, A. R. Tannenbaum, Georgia Institute of Technology (United States)

7532 OL Image analysis and classification by spectrum enhancement: new developments [7532-21] G. F. Crosta, Univ. degli Studi di Milano-Bicocca (Italy)

7532 OM Gabor feature based class-dependence feature analysis for face recognition [7532-22]

Z. Han, C. Fang, X. Ding, Tsinghua Univ. (China)

INTERACTIVE PAPER SESSION

753200 An improved framework for automatic image mosaic [7532-24]

J. Lei, J. Ding, J. Liu, Zhejiang Univ. (China) and Zhejiang Provincial Key Lab. of Information Network Technology (China)

$75320 Q \quad$ Morphological rational multi-scale algorithm for color contrast enhancement [7532-26] H. Peregrina-Barreto, Univ. Autónoma de Querétaro (Mexico); I. R. Terol-Villalobos, CIDETEQ (Mexico)

7532 OS Estimation of circularly symmetric point spread function for digital auto-focusing [7532-28] Y. Park, J. Lee, J. Jeon, J. Paik, Chung-Ang Univ. (Korea, Republic of) 
7532 OT Hierarchical representation of objects using shock graph methods [7532-29] S. P. Hingway, G.H. Raisoni Polytechnic (India); K. M. Bhurchandi, Ramdeobaba Kamla Nehru College of Engineering (India)

$7532 \mathrm{OU}$ Hand-movement-based in-vehicle driver/front-seat passenger discrimination for centre console controls [7532-30]

E. Herrmann, A. Makrushin, J. Dittmann, Otto-von-Guericke-Univ. of Magdeburg (Germany); C. Vielhaver, Univ. of Applied Sciences Brandenburg (Germany); M. Langnickel, Technical Univ. of Berlin (United States); C. Kraetzer, Otto-von-Guericke-Univ. of Magdeburg (Germany)

$7532 \mathrm{OV}$ The feasibility test of state-of-the-art face detection algorithms for vehicle occupant detection [7532-31]

A. Makrushin, J. Dittmann, Otto-von-Guericke-Univ. of Magdeburg (Germany); C. Vielhaver, Univ. of Applied Sciences Brandenburg (Germany); M. Langnickel, Technical Univ. of Berlin (Germany); C. Kraetzer, Otto-von-Guericke-Univ. of Magdeburg (Germany)

7532 oW Novel medical image enhancement algorithms [7532-32]

S. Agaian, S. A. McClendon, The Univ. of Texas at San Antonio (United States)

7532 0X Use of satellite image enhancement procedures for global cloud identification [7532-33] J. R. Dim, H. Murakami, M. Hori, Japan Aerospace Exploration Agency (Japan)

7532 OY Robust steganographic method based on center weighted median algorithm [7532-35] B. E. Carvajal-Gámez, F. J. Gallegos-Funes, J. L. López-Bonilla, V. Ponomaryov, National Polytechnic Institute of Mexico (Mexico)

$753211 \quad$ Anisotropic diffusion with monotonic edge-sharpening [7532-38] W. Ma, Guangdong Univ. of Foreign Studies (China); Y.-L. You, M. Kaveh, Univ. of Minnesota (United States)

753215 Multiple description video coding technique based on data hiding in the tree structured Haar transform domain [7532-42]

M. Cancellaro, M. Carli, A. Neri, Univ. degli Studi Roma Tre (Italy)

753216 Reversible data hiding in the Fibonacci-Haar transform domain [7532-43]

F. Battisti, M. Carli, A. Neri, Univ. degli Studi Roma Tre (Italy)

753217 A memory-efficient and time-consistent filtering of depth map sequences [7532-45]

S. Smirnov, A. Gotchev, K. Egiazarian, Tampere Univ. of Technology (Finland)

Author Index 
Downloaded From: https://www.spiedigitallibrary.org/conference-proceedings-of-spie on 26 Apr 2023

Terms of Use: https://www.spiedigitallibrary.org/terms-of-use 


\title{
Conference Committee
}

\author{
Symposium Chair \\ Jan P. Allebach, Purdue University (United States) \\ Symposium Cochair
}

Sabine Süsstrunk, Ecole Polyłechnique Fédérale de Lausanne

(Switzerland)

Conference Chairs

Jaakko T. Astola, Tampere University of Technology (Finland)

Karen O. Egiazarian, Tampere University of Technology (Finland)

Program Committee

Til Aach, RWTH Aachen (Germany)

Sos S. Agaian, The University of Texas at San Antonio (United States)

Junior Barrera, Universidade de São Paulo (Brazil)

Reiner Creutzburg, Fachhochschule Brandenburg (Germany)

Paul D. Gader, University of Florida (United States)

Atanas P. Gotchev, Tampere University of Technology (Finland)

John C. Handley, Xerox Corporation (United States)

Vladimir V. Lukin, National Aerospace University (Ukraine)

Stephen Marshall, University of Strathclyde (United Kingdom)

Alessandro Neri, Università degli Studi di Roma Tre (Italy)

Françoise J. Prêteux, Institut National des Télécommunications

(France)

Giovanni Ramponi, Università degli Studi di Trieste (Italy)

Jagath K. Samarabandu, The University of Western Ontario (Canada)

Ivan W. Selesnick, Polytechnic Institute of NYU (United States)

Akira Taguchi, Musashi Institute of Technology (Japan)

Session Chairs

$1 \quad$ Imaging Filtering

Karen O. Egiazarian, Tampere University of Technology (Finland)

2 Image Processing Algorithms I

Marco Carli, Università degli Studi di Roma Tre (Italy)

3 Image Processing Algorithms II

Marco Carli, Università degli Studi di Roma Tre (Italy) 
$4 \quad$ Image and Video Compression

Karen O. Egiazarian, Tampere University of Technology (Finland)

$5 \quad$ Image Recognition

Karen O. Egiazarian, Tampere University of Technology (Finland)

Interactive Paper Session

Neil A. Dodgson, University of Cambridge (United Kingdom)

Andrew J. Wood, Curtin University of Technology (Australia) 